\title{
R Resercrch Suare \\ The Effect of Modification of Technology Monitoring on Relationship Between Corporate Governance, Credit Monitoring, and Npl
}

Maswar Purnama ( $\nabla$ maswar@student.ub.ac.id)

Suhadak

Sri Mangesti

Cacik Rut Damayanti

Research

Keywords: Non-Performing Loan, Corporate Governance, Technology Monitoring

Posted Date: June 9th, 2020

DOI: https://doi.org/10.21203/rs.3.rs-33949/v1

License: (c) (i) This work is licensed under a Creative Commons Attribution 4.0 International License.

Read Full License 


\section{Abstract}

Purpose: This study aims to examine whether there is a moderation effect of Technology Monitoring in the relationship between Corporate Governance and Credit Monitoring variables on the drivers of NPL.

Design/Method: This research is a quantitative research. The data in this study are a combination of primary data obtained through questionnaires and also secondary data obtained from bank credit portfolios. The research took place at the Micro Branch Office of Bank Mandiri in Central Java Region with the head of the branch office as a sample in this study. The sampling technique used is Judgment Sampling and data analysis using SEM.

Findings: The results showed that Corporate Governance had a positive and significant effect on Credit Monitoring, Corporate Governance had a negative and significant effect on NPL, Credit Monitoring had a negative and significant effect on NPL Technology Monitoring had a positive and not significant effect in moderating the relationship between Corporate Governance on NPL and the influence of Technology Monitoring a positive and significant effect in moderating the relationship between Credit Monitoring for NPL.

Originality: The originality of this research lies in testing the effect of Corporate Governance and Credit Monitoring on Non-Performing Loans with the updating of Technology Monitoring as a moderating variable.

\section{Introduction}

The implementation of Corporate Governance (CG) in the banking world has increasingly developed in the last few decades. The world of credit, which is the pulse of the banking industry, is also growing due to the development of the "hedonism" lifestyle and the rapid globalization. Responding to these developments, each bank has now begun to change the mindset in implementing CG. Currently every bank has superior jargon in implementing a complete CG such as the ASEAN Corporate Governance Scorecard and Whistleblowing System.

The Bank does not only take preventive actions against bad loans at the beginning of the transaction through CREDIT MONITORING, but also takes curative actions during the credit period through Credit Monitoring. Credit Monitoring is not only a focus for banks, other companies also have a Credit Monitoring system to control their corporate debt. Sometimes a company still has assets that still bear the debt that needs to be monitored so as not to become a loss in the future. Regulations (OJK, 2017) also require the Risk Management Committee to take part in Credit Monitoring (OJK, 2017).

Banks as the main movers of credit certainly have a special division in conducting Credit Monitoring. The division is tasked specifically to carry out monitoring actions on all bank creditors and take special preventive measures against creditors who have an indication of bad credit. As one element in the bank structure, Credit Monitoring cannot be released from CG. The choice of preventive, supervisory and non- 
performing loan enforcement methods must be based on the corporate governance system. So that the quality of $\mathrm{CG}$ of an organization / banking also gives a role to the quality of the credit monitoring itself.

The problem of Non performing Loan (NPL) is a big challenge for the banking world because since the banking restructuring program began, the ratio of Non performing Loan (NPL) has been difficult to achieve the ideal number. If banks are able to reduce the ratio of Non performing Loan (NPL), the potential benefits to be gained will be even greater because banks will save money that will be needed to back up Non performing Loan (NPL) losses.

The object of research in this study is PT Bank Mandiri (Persero) Tbk. The high NPL at PT Bank Mandiri (Persero) Tbk, can have a large impact on the sustainability of the company. According to the FSA regulation No. 42 / POJK.03 / 2017 concerning bad loans, the highest limit of NPLs at banks is 5\%. If the limit is exceeded, the bank must reduce the amount of credit granted. The reduction in the amount of credit certainly has an impact on the decline in bank income from the credit sector. In addition, the high NPL also increases the risk for the bank's capital availability. Therefore, steps must be taken to reduce the risk of PT Bank Mandiri (Persero) Tbk's NPL, going forward.

Some previous studies such as Ko, Lee and Anandarajan (2001) state that the type of corporate governance can influence the type of corporate supervision over assets that are strengthened by research from Mili and Abid (2016). Tarchouna's research (2017) states that corporate governance can influence decision making on risky investments. Credit is a way for banks to invest capital that is owned despite high risk. Saada (2017) states that good corporate governance of a bank can facilitate banks in conducting supervision of bad loans, which strengthens research from Tarchouna (2017). Piatti and Cincinelli's research (2019) states that the weakness of a bank's credit supervision is the main problem in the high bad loans at the bank.

Search results through the study of previous research libraries also have not found a comprehensive study involving all of these variables. Comprehensive research will provide more accurate analysis results because it considers that NPL can be influenced by several factors, namely CG and Credit Monitoring. This study also revealed that Technology Monitoring provides a moderating role that increases the influence of CG and Credit Monitoring variables on NPL. No previous research has been found that tested the moderation of Technology Monitoring on the influence of CG and Credit Monitoring on NPLs as well as being novelty in this study.

\section{Literature Review and Hypotheses Development}

This research uses Financial Intermediation Monitoring Theory. The Financial Intermediation Monitoring Theory (Diamond, 1984) states that optimal oversight by stakeholders in company positions can minimize the risk of investment. Diamond also added that delegated monitoring conducted by the company is one way to reduce monitoring cost without sacrificing the effectiveness of supervision. 
Corporate governance according to The Indonesian Corporate Governance Manual $(0 J K, 2017)$ issued by the Financial Services Authority is a system of relationships within companies that are governed by structures and processes. Corporate governance refers to the way companies are governed and for what purpose. It identifies who has power and accountability, and who makes decisions. This, in essence, is a tool that allows management and the board to deal with company matters more effectively. Corporate governance ensures that business policies have the right decision-making and control processes so that the interests of all stakeholders (shareholders, employees, suppliers, customers and society) are balanced. Governance at the company level covers the process in which company objectives are set and implemented in context social environment, regulations and markets. This relates to practices and procedures to ensure that the company is run in such a way as to achieve its objectives, while ensuring that stakeholders can have confidence that their trust in the company has been carried out properly.

The biggest asset of a bank is credit. 80 percent of assets from banks are credit. Credit needs to be monitored because it requires a long process, so monitoring and coaching is needed. Some risks include: rising interest rates, inflation, changes in the value of a currency against foreign currencies. Nonperforming loans do not happen suddenly. Monitoring is a tool to monitor credit to prevent irregularities. Monitoring is needed because the magnitude of the impact of credit quality (collectibility) on the continuity of bank business, can prevent problems from becoming larger, and because every process of asset conversion can be exposed to potential risks. This risk exists in every form and type of activity, including in the process of bank branch activities. It's just that the intensity of the risk is different in each form and type of activity. These risks must be anticipated so that the negative impact on credit can be minimized. There will not be a sudden bad credit if the stages in the crediting process are followed properly. If a bank has been monitoring well, it means that the bank has run an early warning system, where early detection is carried out to find out indications that are potential risks for bank credit. Indications of deviation can be detected through several types of monitoring. The more efficient type of monitoring depends a lot on the use of manpower, time, cost, and risk faced because banks will always consider this. These indications are deviations from the terms of lending, which is essentially the provisions of the monetary authority, bank provisions, prerequisites / conditions, and the results of negotiations between the bank and the customer.

Non performing loan according to Rottke and Gentgen (2008), is a permanent phenomenon that is present in neCredit Monitoringa banks and other lending institutions. Increasing credit poses significant problems for neCredit Monitoringa banks and the emergence of market Non Performing Loan (NPL) is a temporary phenomenon. In this study, the analysis of the relationship between cost efficiency and NPL is ambivalent. The higher the NPL-volume the lower the cost of efficiency. However, it can also cause an increase in bad loans. According to Ozili (2019), NPL is important because it reflects the credit quality of the bank's portfolio, and in the collection of regulations reflects the credit quality of the bank's portfolio in the country. Understand policies that affect the level of risk and no financial risk is not responsible for financial risk.

\section{Research methodology}


This research is a quantitative research. The data in this study are a combination of primary data obtained through questionnaires and also secondary data obtained from bank credit portfolios. This research was conducted at Bank Mandiri in the Jawa Tengah Province. Research data were collected from Bank Mandiri branch offices. The sampling technique used in this study is Judgment Sampling where the sample is chosen based on certain criteria. The population in this study were all 7 areas of Bank Mandiri in the Jawa Tengah Region. The criteria used are micro branch offices (KCM) in 3 areas with the largest loan portfolio in Jawa Tengah.

Table 1 shows the size of the loan portfolio per area in Bank Mandiri in Jawa Tengah Region. From this table, it can be seen that the Semarang area loan portfolio is the largest contributor to the portfolio with a total portfolio of Rp 2,467 trillion, followed by the Solo area with a portfolio of Rp 1,884 trillion and the

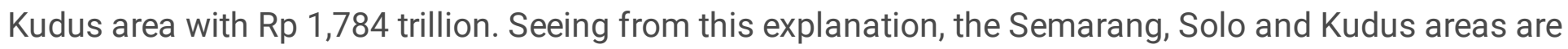
sampled in this study. Data will be analyzed using SEM technique. The use of SEM method is based on the reason SEM has an advantage in confirming the relationship theory between variables contained in the structural model and or testing the relationship between variables whose theoretical basis is weak or even does not yet exist.

Table 1

Credit Portfolio by Area

\begin{tabular}{|lll|}
\hline No & Area & Credit Portfolio (million) \\
\hline 1 & Semarang & Rp 2.467.502 \\
\hline 2 & Yogyakarta & Rp 1.694.910 \\
\hline 3 & Solo & Rp 1.884.735 \\
\hline 4 & Tegal & Rp 1.005.202 \\
\hline 5 & Purwokerto & Rp 1.347.627 \\
\hline 6 & Kudus & Rp 1.784.228 \\
\hline & Area & Credit Portfolio (million) \\
\hline 7 & Magelang & Rp 524.499 \\
\hline \multirow{2}{*}{ Sumber: Credit report Bank Mandiri (2019) } \\
\hline
\end{tabular}

Conceptual model of research

Here are the hypotheses of this research:

H1: Corporate Governance has a significant effect on Credit Monitoring

H2: Corporate Governance has a significant effect on Non-Performing Loan (NPL)

H3: Credit Monitoring has a significant effect on Non-Performing Loan (NPL) 
H4: Tecnology Monitoring as a moderation of the influence of Corporate Governance on Non-Performing Loan (NPL)

H5: Tecnology Monitoring as a moderation Effect of Credit Monitoring on Non-Performing Loan (NPL)

\section{Results And Discussion}

\subsection{Model Measurement}

The following is a summary of the average indicator and outer loading of each indicator.

Table 2 shows the results that all indicators of latent variables in this study were significant. In the Corporate Governance variable, the Responsibility indicator (X13) is the indicator with the greatest influence with a loading value of 0.263 and an average indicator of 4.48 . While in the Technology Monitoring Variable, the Objective indicator (X22) is the indicator with the greatest influence with a loading value of 0.469 and an average indicator of 4.44 . While the Client Monitoring indicator (Y11) is the indicator with the biggest influence on the Credit Monitoring Variable with a loading value of 0.369 and an average indicator of 4.41 . Table 2 will explain the measurement of the manifest variable used in this study.

Table 2

Measurement of the Latent Variable Research Model

\begin{tabular}{|c|c|c|c|c|}
\hline Variable & Indicator & $\begin{array}{l}\text { Average } \\
\text { Indicator }\end{array}$ & $\begin{array}{l}\text { Outer } \\
\text { Loading }\end{array}$ & $\begin{array}{l}\text { p- } \\
\text { value }\end{array}$ \\
\hline \multirow{5}{*}{$\begin{array}{l}\text { Corporate Governance } \\
\text { (X1) }\end{array}$} & Transparency (X11) & 4.22 & 0.249 & 0.010 \\
\hline & Accountability (X12) & 4.22 & 0.247 & 0.010 \\
\hline & Responsibility (X13) & 4.48 & 0.263 & 0.007 \\
\hline & Independence (X14) & 4.41 & 0.244 & 0.011 \\
\hline & Fairness (X15) & 4.24 & 0.249 & 0.010 \\
\hline \multirow{3}{*}{$\begin{array}{l}\text { Technology Monitoring } \\
\text { (X2) }\end{array}$} & Organization(X21) & 4.40 & 0.449 & $<0.001$ \\
\hline & Purpose (X22) & 4.44 & 0.469 & $<0.001$ \\
\hline & Implementation (X23) & 4.36 & 0.317 & 0.001 \\
\hline \multirow[t]{3}{*}{ Credit Monitoring (Y1) } & Client Oversight (Y11) & 4.41 & 0.369 & $<0.001$ \\
\hline & $\begin{array}{l}\text { Bank Portfolio Supervision } \\
(\text { Y12) }\end{array}$ & 4.01 & 0.439 & $<0.001$ \\
\hline & Credit Supervision (Y13) & 4.25 & 0.409 & $<0.001$ \\
\hline
\end{tabular}


Table 3 shows the results that all manifest indicators in this study were significant. After measuring the research model of each variable, it is necessary to measure the Goodness of fit of the model under study.

Table 3

Measurement of Research Model Manifest Variables

\begin{tabular}{|lllll|}
\hline Variable & Item & Modus & Outer Loading & p-value \\
\hline NPL (Y2) & NPL (Y211) & $0-0.5 \%$ & 1.000 & $<0.001$ \\
\hline
\end{tabular}

\subsection{Goodness of Fit}

Model feasibility test or Goodness of Fit testing the suitability / suitability of the model with the research data owned. Goodness of fit in question is an index or measure of the goodness of relationships between variables.

Table 4 summarizes the results obtained in the analysis and the recommended values for measuring the feasibility of the model. Based on the results of the overall model feasibility testing all criteria have reached the expected value limit or have met the critical limits of the recommended Goodness of fit indices, so that the results of this modeling can be accepted or worthy of analysis. 
Table 4

Model Feasibility Test Results

\begin{tabular}{|c|c|c|c|c|}
\hline No. & Model Fit & Value & Criteria & Conclusion \\
\hline 1 & Average path coefficient & $\begin{array}{l}A P C=0.277 \\
P=0.002\end{array}$ & $P<0.05$ & Significant \\
\hline 2 & Average R-squared & $\begin{array}{l}\text { ARS }=0.382 \\
P<0.001\end{array}$ & $P<0.05$ & Significant \\
\hline 3 & Average adjusted R-squared & $\begin{array}{l}\text { AARS }=0.361 \\
P<0.001\end{array}$ & $P<0.05$ & Significant \\
\hline 4 & Average block VIF & $\mathrm{AVIF}=2.116$ & $\begin{array}{l}\text { acceptableif AVIF } \leq 5 \\
\text { ideal if } \mathrm{AVIF} \leq 3.3\end{array}$ & Ideal \\
\hline 5 & Average full collinearity VIF & AFVIF $=3.440$ & $\begin{array}{l}\text { acceptableif AFVIF } \leq 5 \\
\text { ideal if AFVIF } \leq 3.3\end{array}$ & Acceptable \\
\hline 6 & TenenhausGoF & $\mathrm{GoF}=0.501$ & $\begin{array}{l}\text { kecilifGoF } \geq 0.1 \\
\text { medium ifGoF } \geq 0.25 \\
\text { besarifGoF } \geq 0.36\end{array}$ & Large \\
\hline 7 & Sympson's paradox ratio & $S P R=0.875$ & $\begin{array}{l}\text { acceptable if SPR } \geq \\
0.7 \\
\text { ideal if SPR }=1\end{array}$ & Acceptable \\
\hline 8 & R-squared contribution ratio & $\mathrm{RSCR}=0.988$ & $\begin{array}{l}\text { acceptable if RSCR } \geq \\
0.9 \\
\text { ideal RSCR }=1\end{array}$ & Acceptable \\
\hline 9 & Statistical suppression ratio & $S S R=1.000$ & acceptableif SSR $\geq 0.7$ & Acceptable \\
\hline 10 & $\begin{array}{l}\text { Nonlinear bivariate causality } \\
\text { direction ratio }\end{array}$ & $\begin{array}{l}\text { NLBCDR }= \\
1.000\end{array}$ & $\begin{array}{l}\text { acceptableif NLBCDR } \\
\geq 0.7\end{array}$ & Acceptable \\
\hline
\end{tabular}

\subsection{SEM analysis}

Structural model testing (structural models) essentially tests the hypothesis in research. Inner model is a model of relationships between variables. Significant influence between one variable on another variable is indicated if the $p$-value $<0.05$. The results of direct effects are presented in Table 5 . 
Table 5

Hypothesis Test Results Influence Between Variables

\begin{tabular}{|c|c|c|c|}
\hline Variable Relationship & $\begin{array}{l}\text { Path } \\
\text { Coefficient }\end{array}$ & $\begin{array}{l}\text { p- } \\
\text { value }\end{array}$ & Conclusion \\
\hline Corporate Governance for Credit Monitoring & 0.607 & $<0.001$ & Significant \\
\hline Corporate Governance for Non-Performing Loan (NPL) & -0.530 & $<0.001$ & Significant \\
\hline Credit Monitoring for Non-Performing Loan (NPL) & -0.339 & $<0.001$ & Significant \\
\hline $\begin{array}{l}\text { Moderating of TechnologyMonitoringfor influence } \\
\text { CorporategovernancetowardsNon-Performing Loan (NPL) }\end{array}$ & 0.079 & 0.239 & $\begin{array}{l}\text { Not } \\
\text { Significant }\end{array}$ \\
\hline $\begin{array}{l}\text { Moderating of TechnologyMonitoringfor influence Risk } \\
\text { Acceptance towardsNon-Performing Loan (NPL) }\end{array}$ & 0.213 & 0.024 & Significant \\
\hline
\end{tabular}

\subsection{Discussion}

\section{H1: Corporate Governance has a significant effect on Credit Monitoring}

The results from Table 5 show that the Effect of Corporate Governance (X1) on Credit Monitoring (Y1), obtained a structural coefficient of 0.61 and $p$-value $<0.001$. Because $p$-value $<0.05$, and the coefficient marked positive indicates that there is a significant and positive influence between Corporate Governance (X1) on Credit Monitoring (Y1), meaning that the higher the Corporate Governance (X1), will increase the value of Credit Monitoring (Y1). Thus, hypothesis 1 of this study was accepted.

The results of this study are in line with Ko, Lee and Anandarajan (2001) stating that the type of corporate governance can affect the type of corporate supervision over assets that are strengthened by research from Mili and Abid (2016). The results of the study indicate that corporate governance in the Bank's micro branch offices Mandiri Central Java is a decisive factor in Credit Monitoring carried out by banks in supervising credit. If the bank wants to improve the quality of Credit Monitoring, Bank Mandiri needs to improve Responsibility as a major factor in the Corporate Governance variable.

\section{H2: Corporate Governance has a significant effect on Non-Performing Loans (NPL)}

The results of Table 5 show that the Effect of Corporate Governance (X1) on Non-Performing Loans (NPL) (Y2), obtained a structural coefficient of -0.53 and $p$-value $<0.001$. Because the $p$-value $<0.05$, and the coefficient marked negative indicates that there is a significant and negative influence between Corporate Governance (X1) on Non-Performing Loans (NPL) (Y2), meaning that the higher the Corporate Governance $(X 1)$, will reduce the value of Non-Performing Loans (NPL) (Y2). Thus, hypothesis 2 of this study was accepted.

The results of this study are in line with Tarchouna (2017) stating that corporate governance can influence decision making towards risky investments. Credit is a way for banks to invest capital that is owned despite high risk. Saada (2017) states that good corporate governance of a bank can make it 
easier for banks to supervise bad loans. The results of the study show that corporate governance in the micro branches of Bank Mandiri in Jawa Tengah is a significant factor in determining the level of NPL. As a credit provider, Bank Mandiri wants a low level of NPL so as not to cause losses. In order to reduce the rate of NPLs, Bank Mandiri needs to increase Responsibility as the main factor in the Corporate Governance variable in order to reduce the level of NPL.

\section{H3: Credit Monitoring has a significant effect on Non-Performing Loan (NPL)}

The results from Table 5 show that the Effect of Credit Monitoring (Y1) on Non-Performing Loans (NPL) (Y2), obtained a structural coefficient of -0.34 and $p$-value $<0.001$. Because $p$-value $<0.05$, and the coefficient marked negative indicates that there is a significant and negative influence between Credit Monitoring (Y1) on Non-Performing Loans (YPL) (Y2), meaning that the higher the Credit Monitoring (Y1), will reduce the value of Non-Performing Loans (NPL) (Y2). Thus, hypothesis 3 of this study was accepted.

The results of this study are in line with the Piatti and Cincinelli Research (2019) which states that the weakness of a bank's credit supervision is the main problem in the high non-performing loans at the bank. The results showed that Credit Monitoring in the micro branch office of Bank Mandiri in Jawa Tengah had a significant influence in determining the level of NPLs. Negative outer loading indicates that the higher the value of Credit Monitoring will further reduce the NPL rate. This is in line with the purpose of Credit Monitoring which aims to minimize the existence of bad credit.

\section{H4: Tecnology Monitoring as a moderation of the influence of Corporate Governance on Non-Performing Loan (NPL)}

The results of Table 5 show that the Effect of Moderation Technology Monitoring (X2) on the influence of Corporate Governance (X1) on Non-Performing Loan (NPL) (Y2), obtained a structural coefficient of 0.08 and a p-value of 0.24 . Because $p$-value $>0.05$, and the coefficient marked positive indicates that there is an insignificant and positive influence on Moderation Technology Monitoring (X2) on the influence of Corporate Governance (X1) on Non-Performing Loans (NPL) (Y2). Thus, hypothesis 4 of this study was not accepted.

The absence of previous research examining the influence of moderating Technology Monitoring on the relationship between Corporate Governance and NPL is a novelty in this study. Unfortunately in this study it was revealed that there was no significant moderation effect from Technology Monitoring on the influence relationship between CG and NPL. This can be caused by the implementation of monitoring technology in Bank Mandiri which is something that has just begun so that there is no significant impact felt by Bank Mandiri from the application of Technology Monitoring in moderating the relationship between CG and NPL.

H5: Technology Monitoring as a moderation Effect of Risk Acceptance on Non-Performing Loans (NPL) 
The results of Table 5 show that the Effect of Moderation Technology Monitoring (X2) on the influence of Corporate Governance (X1) on Non-Performing Loans (NPL) (Y2), obtained a structural coefficient of 0.21 and a $p$-value of 0.02 . Because the $p$-value $<0.05$, and the coefficient marked positive indicates that there is a significant and positive influence on Moderation Technology Monitoring (X2) on the influence of Corporate Governance (X1) on Non-Performing Loans (NPL) (Y2). Thus, hypothesis $\mathbf{5}$ of this study was accepted.

The absence of previous studies examining the effect of moderating Technology Monitoring on the relationship between Credit Monitoring and NPL is a novelty in this study. The results of this study suggest that there is a significant moderation effect of Technology Monitoring on the influence relationship between Credit Monitoring and NPL. A positive outer loading value also indicates that Technology Monitoring strengthens the influence between Credit Monitoring and NPL. This is in line with the purpose of Technology Monitoring in helping and facilitating the Credit Monitoring process in order to reduce the rate of NPL.

Here is a picture of the results of the direct effect:

\section{Indirect Effect of Corporate Governance on NPL through Credit Monitoring Mediation}

The results from table 6 show that Corporate Governance has a negative and significant effect on NPL with mediation from Credit Monitoring. P value $<0.05$ indicates that CG with Credit Monitoring mediation has a significant effect on NPL and the coefficient of -0.219 indicates that the greater the level of Corporate Governance mediated by Credit Monitoring will help in suppressing the rate of NPLs. The results of the direct and indirect effects show that Corporate Governance and Credit Monitoring both partially and simultaneously are one of the significant factors in suppressing the NPL rate. Banks are expected to be able to integrate their Corporate Governance and Credit Monitoring systems to reduce the rate of NPLs to remain within normal limits.

Table 6

Estimated Results and Testing of Indirect Effects

Effect between Latent variables

Path coefficient

p-value Conclusion

Predictor Variable $\quad \rightarrow$ Response Variable

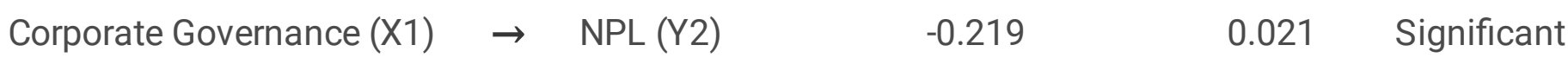

\section{Conclusion And Recommendation}

From the research results previously explained, the following conclusions can be drawn: Corporate Governance has a positive and significant effect on Credit Monitoring, Corporate Governance has a negative and significant effect on NPL, Credit Monitoring has a negative and significant effect on NPL Technology Monitoring has a positive and not significant effect in moderating the relationship between 
Corporate Governance and NPLs and the influence of Technology Monitoring has a positive and significant effect in moderating the relationship between Credit Monitoring and NPLs

Bank Mandiri needs to strengthen and strengthen Corporate Governance and Credit Monitoring as a significant driver of reducing the NPL rate. Corporate Governance also has an important role in improving the quality of Credit Monitoring. The effect of corporate governance and credit monitoring simultaneously or partially has been proven to have a significant effect on the decline in the NPL rate.

This study aims to provide input to company management, especially banks in order to improve corporate governance and provide input to the banking world in developing policies to reduce the rate of NPL. This research is also expected to assist Bank Mandiri in determining the right and appropriate policies in providing credit to customers.

\section{Declarations}

\section{Author's Profile}

1. MaswarPurnama is a doctoral student in major of Business Administration, Faculty of Administrative Sciences, University of Brawijaya as well as senior vice president of Bank Mandiri in Central Java and DIY.

2. Prof. Dr.Suhadak, M.Ec. is currently as a lecturer in major of Business Administration, Faculty of Administrative Sciences, University of Brawijaya.

3. Dra. Sri MangestiRahayu, M.Si. is currently as a lecturer in major of Business Administration, Faculty of Administrative Sciences, University of Brawijaya.

4. Cacik Rut Damayanti, S.Sos. M.Prof.Acc., DBA is currently as a lecturer in major of Business Administration, Faculty of Administrative Sciences, University of Brawijaya.

\section{Funding}

This research did not receive any specific grant from funding agencies in the public, commercial, or notfor-profit sectors.

\section{Conflicts of interest}

The authors declare no conflicts of interest.

\section{Availability data and material}

Data available on request due to privacy/ethical restrictions

\section{Ethics approval}

Approval was obtained from the local ethics committee 


\section{References}

1. Bolt, W., \& Tieman, A. F. (2004). Banking competition, risk and regulation. Scandinavian Journal of Economics, 106(4), 783-804.

2. Diamond, D. W. (1984). Financial intermediation and delegated monitoring. The review of economic studies, 51(3), 393-414.

3. Ko, C., Lee, P., \& Anandarajan, A. (2019). The Impact of Operational Risk Incidents and Moderating Influence of Corporate Governance on Credit Risk and Firm Performance. International Journal of Accounting \& Information Management, (just-accepted), 00-00

4. Mili, M., \& Abid, S. (2016). Do corporate bond recovery rates monitored by corporate governance mechanisms?. Managerial Finance, 42(8), 830-848

5. Otoritas Jasa Keuangan (2017). Peraturan Otoritas Jasa Keuangan Nomor 73/POJK. 05/2017 Tentang Tata Kelola Perusahaan Yang Baik Bagi Perusahaan Perasuransian.

6. Ozili, P. K. (2019). Munich Personal RePEc Archive Non-performing loans and Financial Development: New Evidence Central Bank of Nigeria Non-performing loans and Financial Development: New Evidence. 92211

7. Piatti, D., \& Cincinelli, P. (2019). Does the threshold matter? The impact of the monitoring activity on Non-Performing Loans: Evidence from the Italian banking system. Managerial Finance, 45(2), 190221.

8. Rottke, N. B., \& Gentgen, J. (2008). Workout management of non-performing loans. Journal of Property Investment \& Finance.

9. Saada, M. B. (2017). The impact of control quality on the non-performing loans of Tunisian listed banks. Managerial Auditing Journal

10. Tarchouna, A., Jarraya, B., \& Bouri, A. (2017). How to explain non-performing loans by many corporate governance variables simultaneously? A corporate governance index is built to US commercial banks. Research in International Business and Finance, 42, 645-657

\section{Figures}




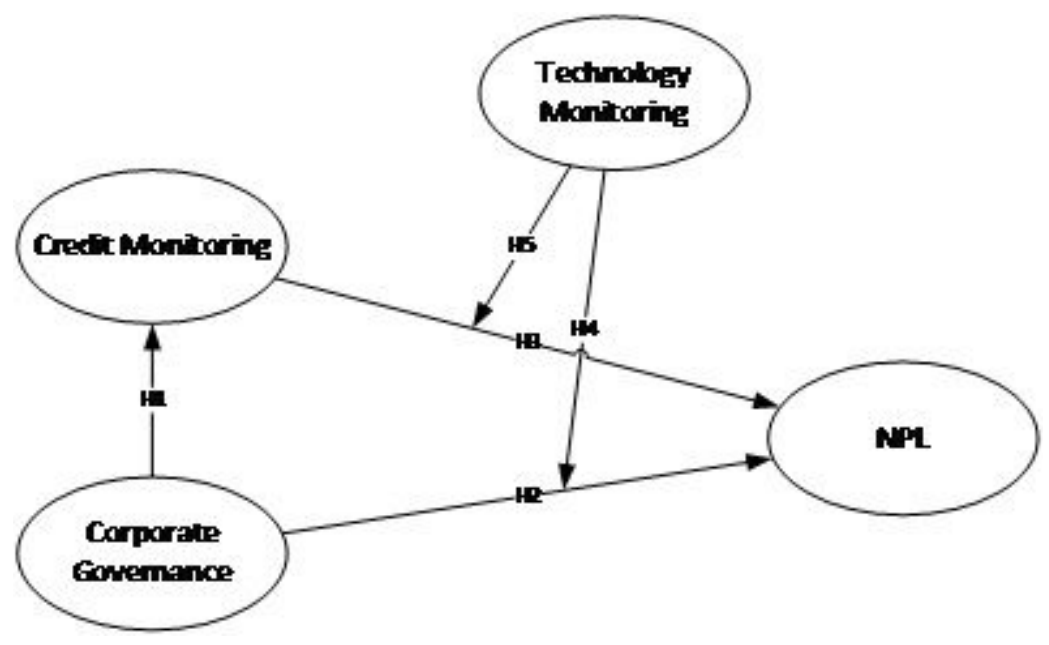

Figure 1

Conceptual Framework

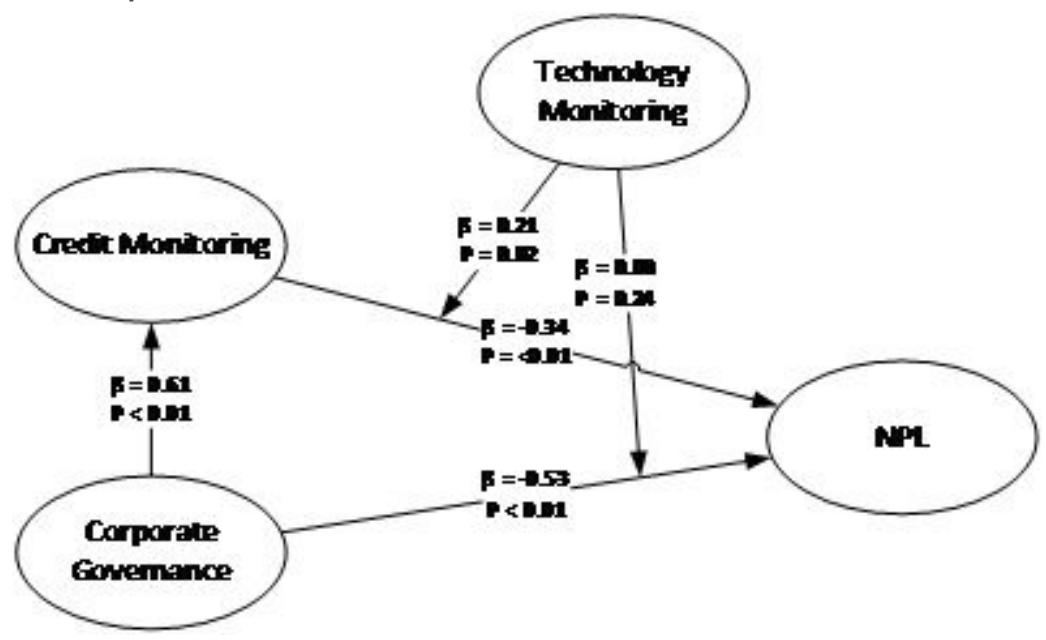

Figure 2

Direct Effect 